\title{
Melanocortin Pathways: Suppressed and Stimulated Melanocortin-4 Receptor (MC4R)
}

\author{
Vojtěch HAINER ${ }^{1}$, Irena ALDHOON HAINEROVÁ ${ }^{1,3}$, Marie KUNEŠOVÁ ${ }^{1}$, \\ Radka TAXOVÁ BRAUNEROVÁ ${ }^{1}$, Hana ZAMRAZILOVÁ ${ }^{1}$, Běla BENDLOVÁ ${ }^{2}$
}

${ }^{1}$ Obesity Management Center, Institute of Endocrinology, Prague, Czech Republic, ${ }^{2}$ Department of Molecular Endocrinology, Institute of Endocrinology, Prague, Czech Republic, ${ }^{3}$ Department of Pediatrics, Third Faculty of Medicine, Charles University and University Hospital Královské Vinohrady, Prague, Czech Republic

Received February 25, 2020

Accepted March 16, 2020

\section{Summary}

Leptin-melanocortin pathway plays an essential role in the body weight regulation. Enhanced melanocortin signaling in the hypothalamus results in both decreased food intake and increased energy expenditure. The discovery of monogenic obesities with dysfunction of melanocortin-4 receptor (MC4R) greatly contributed to understanding of energy balance regulation. This review presents phenotypical characterization and prevalence of the MC4R gene mutations. Genome-wide association studies revealed that MC4R gene is significantly related not only to monogenic obesities but also to common obesity. An interaction of variants in the MC4R gene with fat mass and obesity associated (FTO) gene significantly increases the risk for obesity, particularly in adolescence. On the other hand, about $15 \%$ of the MC4R gene variants result in a gain of function that protects against obesity and is associated with favorable metabolic profile. Long-term attempts to activate the MC4R have recently been finalized by a discovery of setmelanotide, a novel specific MC4R agonist that is devoid of untoward cardiovascular side-effects. The employment of specific MC4R agonists may open new horizons not only in the treatment of rare monogenic obesities but also in some common obesities where stimulation of MC4R could be achieved.

\section{Key words}

Melanocortin-4 receptor (MC4R) function - Monogenic obesity • Common obesity $\bullet$ Gene polymorphisms $\bullet$ MC4R agonists

\section{Corresponding author}

V. Hainer, Obesity Management Center, Institute of Endocrinology, Národní 8, 11694 Prague 1, Czech Republic. E-mail: vhainer@endo.cz

\section{Introduction}

Both melanocortin peptides derived from pro-opiomelanocortin, $\alpha$-melanocyte stimulating hormone $(\alpha-\mathrm{MSH})$ and adrenocorticotrophic hormone were originally related to regulation of pigmentation and adrenocortical hormones secretion (Anderson et al. 2016). However, the cloning of genes that encode melanocortin receptors in 1992 contributed to reveal an additional role of melanocortin system in the regulation of energy homeostasis (Mountjoy et al. 1992). Several hormones affect energy balance through the melanocortin pathways. The effect of leptin, cholecystokinin, fatty acids, ghrelin and serotonin on energy balance is dependent on melanocortin system while the effect of peptide YY, pituitary adenylate cyclase-activating peptide and glutamate on energy balance is independent on melanocortin system (Shen et al. 2017). Adipose tissue derived hormone leptin induces negative energy balance by stimulating $\alpha-\mathrm{MSH}$ and melanocortin-4 receptor (MC4R) (Friedman 1997, Kask et al. 1998). Increased melanocortin signaling in hypotalamus leads not only to decreased food intake but also increases sympathetic nervous system outflow to skeletal muscle, energy expenditure and physical activity (Gavini et al. 2016). A recently published review emphasized the role of the brain $M C 4 R$ for activation of sympathetic nervous system in hypertension (Da Silva et al. 2019). On the other hand, a reduced brain- 
melanocortin activity increases fat mass in experimental animals through signals conveyed by vagus nerve (Holland et al. 2019). In experimental animals agoutirelated peptide (AGRP) suppresses MC4R activity. An ectopic expression of AGRP in mouse leads to obesity and inhibition of eumelanin pigment synthesis (Fan et al. 1997) as AGRP acts as an antagonist of both $M C 4 R$ and $M C 1 R$. A quantitative mass spectrometry for human melanocortin peptides in vitro and in vivo also suggested an important role of $\beta$-MSH and desacetyl $\alpha$-MSH in regulation of energy homeostasis (Kirwan et al. 2018). These authors characterized sequences of more than 20 hypothalamic peptides, most of them being involved in regulation of energy balance. This finding supported previous clinical studies which had demonstrated that children with early onset obesity carrying the Tyr221Cys variant of $\beta$-MSH were hyperphagic and showed increased linear growth, similarly as children with $M C 4 R$ mutations (Lee et al. 2006).

\section{Suppressed MC4R activity in monogenic obesities}

Mutations in genes involved in leptinmelanocortin pathway result in usually early-onset fat accumulation. Cases of severe obesity involve mutations in leptin $(L E P)$, leptin receptor $(L E P R)$, proopiomelanocortin (POMC), $\beta$-MSH, prohormone convertase (PCSK) and MC4R genes. Mutations of $M C 4 R$ are most common forms of monogenic obesities and include mostly missense mutations with different losses of function (Farooqi et al. 2003). Farooqi et al. (2003) defined MC4R syndrome characterized by early-onset obesity, increased linear growth, increased bone mineral density, hyperphagia and hyperinsulinemia. In our Czech cohort, as in several others, $M C 4 R$ mutations were not associated with hyperinsulinemia and increased bone mineral density (Hainerová et al. 2007, Dubern et al. 2001, Lubrano-Berthelier et al. 2004, Mergen et al. 2001). Our study (Hainerová et al. 2007) as well as that of Hebebrand et al. (2004) did not find binge eating as a characteristic phenotype of $M C 4 R$ gene mutations (Branson et al. 2003). The prevalence of $M C 4 R$ mutations greatly varies in different populations, from 0.5 to $5.8 \%$. Until 2013, 166 different obesity-associated mutations of $M C 4 R$ have been reported (Hinney et al. 2013). Among Czech children with early-onset obesity the prevalence of $M C 4 R$ mutations was $2.4 \%$ (Hainerová et al. 2007) whereas that in obese Slovak children was $0.7 \%$, one of the lowest frequencies in Europe (Stanikova et al. 2015).

Similarly to $M C 4 R$ mutations in humans, disruption of the $M C 4 R$ in mice resulted in hyperphagia, obesity and increased linear growth (Huszar et al. 1997). Gavini et al. (2019) has recently described a new trafficking C2-domain protein (C2CD5) located in the paraventricular hypothalamus that involves in $M C 4 R$ endocytosis and energy balance regulation. The loss of functional $\mathrm{C} 2 \mathrm{CD} 5$ protein in knockout mice increased the number of non-functional $M C 4 R$ at the cell surface and resulted in increased food intake in comparison with wild-type mice. In addition, mice lacking C2CD5 exhibited a lower reduction of food intake in response to treatment with $M C 4 R$ agonist. Diet-induced obesity in mice was shown to be associated with blunted expression of C2CD5 in the hypothalamus.

\section{MC4R genes polymorphisms leading to weight gain}

Genome-wide association studies revealed fat mass and obesity associated (FTO) and MC4R genes as the first genes related to common obesity (Frayling et al. 2007, Loos et al. 2008). Obesity risk associated with $M C 4 R$ polymorphisms largely differs between studies carried out in different populations. The risk of severe obesity associated with rs17782313 variant was particularly expressed in childhood (Loos et al. 2008). The risk ratio in 10,583 children from three studies reached 1.30 (1.22-1.41). MC4R variants rs17782313 and rs12970134 showed strong association with adiposity measures in Indian population (Dwivedi et al. 2013). On the other hand, MC4R variant rs12970134 was associated with adiposity measures in Czech women with polycystic ovary syndrome, but not in normoglycemic women and those with type 2 or gestational diabetes (Bradnová et al. 2015). A stronger association of $M C 4 R$ polymorphisms with adiposity was confirmed in children. A metaanalysis of 61 studies that included 80,957 subjects with rs17782313 variant of $M C 4 R$ and 220,223 controls (Xi et al. 2012a) showed a clear association with obesity risk (risk ratio $=1.18, \mathrm{p}<0.001$ ). The association of the $M C 4 R$ rs17782313 C allele with obesity and fat mass deposition was more expressed in males than in females (Cauchi et al. 2009). The interaction of $M C 4 R$ rs17782313 and FTO rs1421085 risk alleles was demonstrated in cohorts of Finnish adolescents $(n=4,762)$ and French adults 
$(\mathrm{n}=3,167)$ (Cauchi et al. 2009). Subjects carrying FTO and $M C 4 R$ risk alleles (7-10\% of studied populations) had a 3-fold increased risk of developing obesity during adolescence. However, such risk declined to 1.8-fold in adulthood. The presence of three or more high-risk alleles of FTO and MC4R genes resulted in 4-fold increase in the risk for obesity in Greek children and adolescents (Lazopoulu et al. 2015). A recent Chinese study confirmed combined effect of FTO and MC4R gene polymorphisms in children and adolescents (Yang et al. 2019). Subjects carrying genotypes of FTO rs9939609, $M C 4 R$ rs17782313 and MC4R rs12970134 had 2.45-fold risk for developing obesity compared to subjects without such polymorphisms.

\section{Reduced function of $M C 4 R$ and metabolic syndrome}

Loss of function in subjects carrying mutations or variants of the $M C 4 R$ is associated with obesity. Such subjects may therefore be predisposed to develop metabolic syndrome. Adipose tissue hormone adiponectin possesses antiatherogenic and antiinflammatory properties and increases insulin sensitivity (Nedvídková et al. 2005) and hypoadiponectinemia in $M C 4 R$ deficiency may contribute to development of metabolic syndrome. Trevaskis et al. (2007) demonstrated that $M C 4 R$ deficiency in MC4R knock-out mice is associated with low levels of adiponectin, insulin resistance and inflammation of adipose tissue. However, an association of the $M C 4 R$ function with metabolic syndrome is not unequivocal because of the decreased sympathetic nervous activity and lower blood pressure accompanying loss of the receptor function. In order to investigate an association of the $M C 4 R$ rs12970134 and rs17782313 variants with metabolic syndrome we studied a cohort of 1,443 adolescents aged 13.0-17.9 years (Dušátková et al. 2013). Our cohort included subjects in different weight categories: underweight $(n=60)$, normal weight $(n=713)$, overweight $(n=194)$ and obese $(n=476)$. The prevalence of metabolic syndrome in this cohort was $7.7 \%$. $M C 4 R$ rs 17782313 variant was significantly associated with metabolic syndrome $(\mathrm{OR}=1.51, \mathrm{p}=0.009)$. The association of the $M C 4 R$ rs12970134 variant with metabolic syndrome was weaker $(\mathrm{OR}=1.40, \mathrm{p}=0.035)$. Increased risk of metabolic syndrome in the studied $M C 4 R$ variants is probably mediated by their effects on abdominal obesity. It was demonstrated, however only in boys, that both $M C 4 R$ variants were related to abdominal circumference (Dušátková et al. 2013). Liu et al. (2010) studied a cohort of 1,890 European and AfricanAmerican youth and observed a significant association of the rs17782313 variant with waist circumference in both genders.

Several studies investigated a relationship between the function of the MC4R and individual components of metabolic syndrome. MC4R activation increases sympathetic nervous activity with subsequent increase in blood pressure and pulse rate (DaSilva et al. 2019). On the other hand, mutations characterized by the $M C 4 R$ deficiency in humans are associated with lower blood pressure, less frequent hypertension, lower heart rate and decreased diurnal urinary excretion of catecholamines (Greenfield et al. 2011).

Both variants of the $M C 4 R$, rs17782313 and rs17700633, were associated with lower high-density lipoprotein cholesterol (Kring et al. 2010) whereas only polymorphism of rs17782313 was related to higher serum triglyceride levels (Katsuura-Kamano et al. 2015, Fernandes et al. 2015).

Studies on association of MC4R with type 2 diabetes yielded conflicting results. However, a meta-analysis of 19 studies which included 123,373 individuals (comprising 34,195 cases and 89,178 controls) revealed that the rs17782313 MC4R polymorphism was significantly associated with the risk of type 2 diabetes in this large cohort (Xi et al. 2012b).

\section{MC4R gene polymorphisms protecting against obesity}

Several polymorphisms of $M C 4 R$ have been found to be related to favorable metabolic profile. Initially the V103I polymorphism of MC4R was associated with decreased risk for developing obesity (Geller et al. 2004, Heid et al. 2005, Young et al. 2007). Later on, large meta-analyses demonstrated that V103I and $\mathrm{I} 251 \mathrm{~L} M C 4 R$ variants reduce the risk of obesity by $21 \%$ in $103 \mathrm{I}$-allele carriers and by $50 \%$ in $251 \mathrm{~L}$-allele carriers (Loos 2011). Meta-analysis of 37 studies conducted by Wang et al. (2010) included 55,195 subjects of different ethnic groups with 19,822 obese cases and 35,373 nonobese controls. In this large cohort subjects with $M C 4 R$ V103I polymorphism had $21 \%$ lower risk for obesity. The prevalence of V103I polymorphism was rather low ranging from $2 \%$ to $5 \%$ in different populations. It should be pointed out that Val103Ile polymorphism of $M C 4 R$ was characterized by 
increased metabolic rate and high rates of glucose oxidation with low fasting serum levels of free fatty acids (Rutanen et al. 2004). The common single nucleotide polymorphism (SNP) of the MC4R gene rs1350341 was associated with lower visceral fat accumulation and higher postprandial carbohydrate accumulation (Adamska-Patruno et al. 2019). The joint effect of $M C 4 R$ and LEP polymorphisms on reduced body weight was demonstrated in females (Hart Sailors et al. 2007). Moreover, subjects carrying both MC4R 103I and LEP A19 alleles exhibited lower BMI over the 9 years of follow-up.

A recently published paper by Lotta et al. (2019) described 61 variants of $M C 4 R$ in half million people in the United Kingdom. These variants greatly differed with regard to function of the $M C 4 R ; 77 \%$ resulted in a loss of function and $15 \%$ in a gain of function. The gain of function in $M C 4 R$ variants was associated with protection against obesity and exhibited signaling bias for the recruitment of $G$ protein-independent $\beta$-arrestin pathways rather than for the recruitment of canonical $G$ proteindependent cyclic adenosine monophosphate (cAMP) production. About $6 \%$ of the studied population carried BMI-lowering genetic variants. Carriers of two alleles promoting gain of function due to $\beta$-arrestin signaling exhibited $50 \%$ lower risk for developing obesity, type 2 diabetes, and coronary artery disease. On the other hand, the gain of $M C 4 R$ function mediated by cAMP did not affect the risk of obesity and cardiometabolic diseases and was associated with an increase in systolic blood pressure.

\section{$M C 4 R$ and weight loss}

Hereditary factors play an important role in weight loss and weight loss maintenance (Hainer et al. 2000, Hainer et al. 2008). Similar weight loss in response to a short-term weight management was observed in $M C 4 R$ mutation carriers and non-carriers (Hainerová et al. 2007). Reinehr et al. (2009) confirmed ability to lose weight in response to a lifestyle intervention in children with $M C 4 R$ mutations with reduced receptor function. However, these children were unable to maintain the weight loss. In a 20-year-old male homozygous $M C 4 R$ mutation carrier a stable body weight was achieved over one year when the patient was treated with anti-obesity drug sibutramine (Aldhoon Hainerová et al. 2011). In the study of Kochkapoor et al. (2016), surprisingly, children carrying $M C 4 R$ risk alleles achieved greater weight loss in response to a short-term lifestyle intervention compared to non-carriers, however their ability to maintain weight loss was limited in the long-term.

Huvenne et al. (2016) reviewed studies on bariatric surgery in patients with heterozygous $M C 4 R$ mutations. The weight loss in 18 mutation carriers was similar as that in noncarriers. On the other hand, a 18-year-old patient with complete $M C 4 R$ deficiency due to homozygous mutation regained his preoperative body weight after initial weight loss and gained additional $6.5 \mathrm{~kg}(+7 \%)$ at 12 months after laparoscopic adjustable gastric banding combined with truncal vagotomy (Aslan et al. 2011). Valette et al. (2012) evaluated weight loss 3 , 6 and 12 months after bariatric surgery in patients with functional $M C 4 R$ mutations and in $M C 4 R$ SNPs. Both $M C 4 R$ mutations and SNPs did not affect weight loss and body composition over the studied period. Recently, the effect of $M C 4 R$ polymorphism on body weight and weight loss after bariatric surgery has been studied in 141 women with extreme obesity (Resende et al. 2018). Women with the rs17782313 MC4R polymorphism $(n=65)$ exhibited higher pre-surgical body weight and BMI than non-carriers $(n=76)$. Twenty four months after bariatric surgery the $\mathrm{BMI}<30 \mathrm{~kg} / \mathrm{m}^{2}$ was achieved in $17 \%$ of the risk allele carriers and in $37 \%$ in non-carriers. Significantly more risk allele carriers than non-carriers maintained $\mathrm{BMI}>35 \mathrm{~kg} / \mathrm{m}^{2}$ (51\% vs. $\left.32 \%\right)$ after surgery as a marker of the treatment failure.

\section{Anti-inflammatory and neuroprotective effects of $M C 4 R$ in multiple sclerosis}

$M C 4 R$ activity in multiple sclerosis was broadly studied by Kamermans et al. (2019). MC4R are expressed in astrocytes, cells which reflect disease progression. $M C 4 R$ immunoreactivity was significantly increased in active lesions of multiple sclerosis compared to controls. An activation of $M C 4 R$ in astrocytes exhibited significant antiinflammatory and neuroprotective effects in vitro. The treatment with $M C 4 R$ agonist setmelanotide significantly reduced expression of reactive astrocyte markers induced by the proinflammatory cytokines tumor necrosis factor- $\alpha$ (TNF- $\alpha$ ) and interferon- $\gamma$ (IFN- $\gamma$ ). On the other hand, setmelanotide increased production of antiinflammatory interleukin-6 and interleukin-11. Neuroprotective effects of $M C 4 R s$ were also studied by Benjamins et al. (2018) who revealed that MC4Rs located on brain oligodendroglia and oligodendroglial precursor 
cells are engaged in activation of pathways that protect against damage of these cells in multiple sclerosis.

\section{$M C 4 R$ agonists}

During past decades there have been several attempts to develop specific $M C 4 R$ agonist in order to treat obese patients with disrupted function of $M C 4 R$. Both experimental and clinical studies demonstrated reduction in food intake and body weight, however, with simultaneous activation of sympathetic nervous system with subsequent increase in blood pressure and heart rate and activation of sexual arousal (Sharma et al. 2019). Five MC4R agonists have so far been investigated in humans (Sharma et al. 2019).

Eight-week treatment with a novel $M C 4 R$ agonist setmelanotide (RM 493) reduced food intake by $35 \%$, induced weight loss by $13.5 \%$ and reduced insulin resistance in diet-induced obese macaques without concomittant increase in blood pressure and heart rate (Kievit et al. 2013). No increase in blood pressure and pulse rate was observed in obese subjects who received subcutaneous infusion of setmelanotide over $72 \mathrm{~h}$ (Chen et al. 2015). Moreover, in this trial setmelanotide compared to placebo significantly increased resting energy expenditure and fat oxidation. Later setmelanotide was evaluated on mutant MC4Rs in cells as well as in experimental studies and clinical trials (Collet et al. 2017). Setmelanotide was about 10 to 20 -fold more efficient ligand than endogenous $\alpha$-MSH at wild type $M C 4 R$. Mice with diet-induced obesity were treated with setmelanotide. Wild type $(M C 4 R+/+)$ and heterozygous $(M C 4 R+/-)$ mice on high fat diet lost weight, while homozygous null (MC4R-/-) mice failed to lose weight in response to setmelanotide treatment. Similar results were obtained in a clinical trial. Patients with heterozygous $M C 4 R$ deficiency and obese controls were treated either with setmelanotide or placebo infusions for 28 days. MC4R deficient subjects lost $3.48 \mathrm{~kg}$ after setmelanotide vs. $0.85 \mathrm{~kg}$ after placebo. Obese controls treated with setmelanotide lost $3.07 \mathrm{~kg}$, while obese subjects obtaining placebo gained $0.90 \mathrm{~kg}$. Setmelanotide treatment should be indicated in patients with loss of function mutations within the MC4R pathway as leptin, leptin receptor, proopiomelanocortin, prohormone convertase 1 and MC4R genes (Ayers et al. 2018). Successful treatments of severely obese patients with both proopiomelanocortin deficiency and leptin receptor deficiency by setmelanotide were reported by Kuhnen et al. (2016) and Clément et al. (2018). Trials investigating an employment of setmelanotide in the treatment of syndromic obesity, e.g. Prader-Willi syndrome, have also been suggested. Moreover, some individuals with common obesity may be sensitive to setmelanotide treatment due to reduced $P O M C$-ergic tone (Muller et al. 2016). However, a minor non-specific stimulation of the $M C 1 R$ by setmelanotide should be seriously considered concerning stimulation of melanocytes. Addition of setmelanotide to GLP-1 receptor agonist liraglutide in the treatment of dietinduced obesity in mice amplified beneficial effect of monotherapy on weight loss, glycemic control and cholesterol profile (Clemmensen et al. 2015). The potential use of this novel combinatorial approaches may open new horizons in the treatment of obesity (Muller et al. 2016).

\section{Conflict of Interest}

There is no conflict of interest.

\section{Acknowledgements}

Supported by the Project MZ ČR - RVO (Institute of Endocrinology EÚ 00023761).

\section{References}

ADAMSKA-PATRUNO E, GOSICK J, CZAJOWSKI P, MALISZEWSKA K, CIBOROWSKI M, GOLONKO A, WAVRUSIEWICZ-KURYLONEK N, CITKO A, WASZCZENIUK M, KRETOWSKI A, GORSKA M: The MC4R genetic variants are associated with lower visceral fat accumulation and higher postprandial relative increase in carbohydrate utilization in humans. Eur J Nutr 58: 2929-2941, 2019. https://doi.org/10.1007/s00394-019-01955-0

ALDHOON HAINEROVÁ I, ZAMRAZILOVÁ H, SEDLÁČKOVÁ D, HAINER V: Hypogonadotropic hypogonadism in a homozygous MC4R mutation carrier and the effect of sibutramine treatment on body weight and obesityrelated health risks. Obes Facts 4: 324-328, 2011. https://doi.org/10.1159/000330763 
ANDERSON EJ, CAKIR I, CARRINGTON SJ, CONE RD, GHAMARI-LANGROUDI M, GILLYARD T, GIMENEZ LE, LITT MJ: 60 years of POMC: regulation of feeding and energy homeostasis by $\alpha$-MSH. J Mol Endocrinol 56: T157-T174, 2016. https://doi.org/10.1530/JME-16-0014

ASLAN IR, RANDIVE SA, ERSOY BA, ROGERS SJ, LUSTIG RH, VAISSE C: Bariatric surgery in a patient with complete MC4R deficiency. Int J Obes (Lond) 35: 457-461, 2011. https://doi.org/10.1038/ijo.2010.168

AYERS KL, GLICKSBERG BS, GARFIELD AS, LONGERICH S, WHITE JA, YANG P, DU L, CHITTENDEN TW, GULCHER JR, ROY S, FIEDOREK F, GOTTESDIENER K, COHEN S, NORTH KE, SCHADT EE, LI SD, CHEN R, VAN DER PLOEG LHT: Melanocortin 4 receptor pathway dysfunction in obesity: patient stratification aimed at MC4R agonist treatment. J Clin Endocrinol Metab 103: 2601-2612, 2018. https://doi.org/10.1210/jc.2018-00258

BENJAMINS JA, NEDELKOSKA L, LISAK RP: Melanocortin receptor subtypes are expressed on cells in the oligodendroglial lineage and signal ACTH protection. J Neurosci Res 96: 427-435, 2018. https://doi.org/10.1002/jnr.24141

BRANSON R, POTOCZNA N, KRAL JG, LENTES KU, HOEHE MR, HORBER FF: Binge eating as a major phenotype of melanocortin 4 receptor gene mutations. N Engl J Med 348: 1096-1103, 2003. https://doi.org/10.1056/NEJMoa021971

BRADNOVÁ O, VEJRAŽKOVÁ D, VAŇKOVÁ M, LUKÁŠOVÁ P, VČELÁK J, STANICKÁ S, DVOŘÁKOVÁ K, BENDLOVÁ B: Metabolic and hormonal consequnces of the "Obesity Risk" MC4R variant (rs12970134) in Czech women. Physiol Res 64 (Suppl 2): S187-S195, 2015. https://doi.org/10.33549/physiolres.933119

CAUCHI S, STUTZMANN F, CAVALCANTI-PROENCA C, DURAND E, POUTA A, HARTIKAINEN AL, MARRE M, VOL S, TAMMELIN T, LAITINEN J, GONZALEZ-IZQUIERDO A, BLAKEMORE AI, ELLIOT P, MEYRE D, BALKAU B, JARVELIN MR, FROGUEL P: Combined effects of MC4R and FTO common genetic variants on obesity in European general populations. J Mol Med (Berl) 87: 537-546, 2009. https://doi.org/10.1007/s00109-009-0451-6

CHEN KY, MUNIYAPPA R, ABEL BS, MULLINS KP, STAKER P, BRYCHTA RJ, ZHAO X, RING M, PSOTA TL, CONE RD, PANARO BL, GOTTESDIENER KM, VAN DER PLOEG LH, REITMAN ML, SKARULIS MC: RM-493, a melanocortin-4 receptor (MC4R) agonist, increases resting energy expenditure in obese individuals. J Clin Endocrinol Metab 100: 1639-1645, 2015. https://doi.org/10.1210/jc.2014-4024

CLEMMENSEN C, FINAN B, FISCHER K, TOM RZ, LEGUTKO B, SEHRER L, HEINE D, GRASSL N, MEYER CW, HENDERSON B, HOFMANN SM, TSCHOP MH, VAN DER PLOEG LH, MULLER TD: Dual melanocortin-4 receptor and GLP-1 receptor agonism amplifies metabolic benefits in diet-induced obese mice. EMBO Mol Med 7: 288-298, 2015. https://doi.org/10.15252/emmm.201404508

CLÉMENT K, BIEBERMANN H, FAROOQI IS, VAN DER PLOEG L, WOLTERS B, POITOU C, PUDER L, FIEDOREJ F, GOTTESDIENER K, KLEINAU G, HEYDER N, SCHEERER P, BLUME-PEYTAVI U, JAHNKE I, SHARMA S, MOKROSINSKI J, WIEGAND S, MULLER A, WEIß K, MAI K, SPRANGER J, GRUTERS A, BLANKENSTEIN O, KRUDE H, KUHNEN P: MC4R agonism promotes durable weight loss in patients with leptin receptor deficiency. Nat Med 24: 551-555, 2018. https://doi.org/10.1038/s41591-018-0015-9

COLLET TH, DUBERN B, MOKROSINSKI J, CONNORS H, KEOGH JM, MENDES DE OLIVEIRA E, HENNING E, POITOU-BERNERT C, OPPERT JM, TOUNIAN P, MARCHELLI F, ALILI R, LE BEYEC J, PÉPIN D, LACORTE JM, GOTTESDIENER A, BOUNDS R, SHARMA S, FOLSTER C, HENDERSON B, O'RAHILLY S, STONER E, GOTTESDIENER K, PANARO BL, CONE RD, CLÉMENT K, FAROOQI IS, VAN DER PLOEG LHT: Evaluation of a melanocortin-4 receptor (MC4R) agonist (Setmelanotide) in MC4R deficiency. Mol Metab 6: 1321-1329, 2017. https://doi.org/10.1016/j.molmet.2017.06.015

DA SILVA AA, Do CARMO JM, WANG Z, HALL JE: Melanocortin-4 receptors and sympathetic nervous system activation in hypertension. Curr Hypertens Rep 21: 46, 2019. https://doi.org/10.1007/s11906-019-0951-X

DUBERN B, CLÉMENT K, PELLOUX V, FROGUEL P, GIRARDET JP, GUY-GRAND B, TOUNIAN P: Mutational analysis of melanocortin-4 receptor, agouti-related protein, and $\alpha$-melanocyte-stimulating hormone genes in severely obese children. J Pediatr 139: 204-209, 2001. https://doi.org/10.1067/mpd.2001.116284 
DUŠÁTKOVÁ L, ZAMRAZILOVÁ H, SEDLÁČKOVÁ B, VČELÁK J, HLAVATÝ P, ALDHOON HAINEROVÁ I, KORENKOVÁ V, BRADNOVÁ O, BENDLOVÁ B, KUNEŠOVÁ M, HAINER V: Association of obesity susceptibility gene variants with metabolic syndrome and related traits in 1,443 Czech adolescents. Folia Biol (Praha) 59: 123-133, 2013.

DWIVEDI OP, TABASSUM R, CHAUHAN G, KAUR I, GHOSH S, MARWAHA RK, TANDON N, BHARADWAJ D: Strong influence of variants near MC4R on adiposity in children and adults: a cross-sectional study in Indian population. J Hum Genet 58: 27-32, 2013. https://doi.org/10.1038/jhg.2012.129

FAN W, BOSTON BA, KESTERSON RA, HRUBY VJ, CONE RD: Role of melanocortinergic neurons in feeding and the agouti obesity syndrome. Nature 385: 165-168, 1997. https://doi.org/10.1038/385165a0

FAROOQI IS, KEOGH JM, YEO GS, LANK EJ, CHEETHAM T, O'RAHILLY S: Clinical spectrum of obesity and mutations in the melanocortin 4 receptor gene. N Engl J Med 348: 1085-1095, 2003. https://doi.org/10.1056/NEJMoa022050

FERNANDES AE, De MELO ME, FUJIWARA CT, PIOLTINE MB, MATIOLI SR, SANTOS A, CERCATO C, HALPERN A, MANCINI MC: Associations between a common variant near the MC4R gene and serum triglyceride levels in an obese pediatric cohort. Endocrine 49: 653-658, 2015. https://doi.org/10.1007/s12020$\underline{015-0616-8}$

FRAYLING TM, TIMPSON NJ, WEEDON MN, ZEGGINI E, FREATHY RM, LINDGREN CM, PERRY JR, ELLIOT KS, LANGO H, RAYNER NW, SHIELDS B, ET AL.: A common variant in the FTO gene is associated with body mass index and predisposes to childhood and adult obesity. Science 316: 889-894, 2007. https://doi.org/10.1126/science.1141634

FRIEDMAN JM: The alphabet of weight control. Nature 385: 119-120, 1997. https://doi.org/10.1038/385119a0

FRIEDMAN JM, HALAAS JL: Leptin and the regulation of body weight in mammals. Nature 395: 763-770, 1998. https://doi.org/10.1038/27376

GAVINI CK, JONES WC 2ND, NOVAK CM: Ventromedial hypothalamic melanocortin receptor activation: regulation of activity energy expenditure and skeletal muscle thermogenesis. J Physiol 594: 5285-5301, 2016. https://doi.org/10.1113/JP272352

GAVINI CK, COOK TM, RADEMACHER DJ, MANSUY-AUBERT V: Hypothalamic C2-domain protein involved in MC4R trafficking and control of energy balance. Metabolism 102: 153990, 2019. https://doi.org/10.1016/j.metabol.2019.153990

GELLER F, REICHWALD K, DEMPFLE A, ILLIG T, VOLLMERT C, HERPETZ S, SIFFERT W, PLATZER M, HESS C, GUDERMANN T, BIEBERMANN H, WICHMANN HE, SCHAFER H, HINNEY A, HEBEBRAND J: Melanocortin-4 receptor gene variant I103 is negatively associated with obesity. Am J Hum Genet 74: 572-581, 2004. https://doi.org/10.1086/382490

GREENFIELD JR: Melanocortin signalling and the regulation of blood pressure in human obesity. J Neuronedocrinol 23: 186-193, 2011. https://doi.org/10.1111/j.1365-2826.2010.02088.x

HAINER V, STUNKARD AJ, KUNEŠOVÁ M, PAŘÍZKOVÁ J, ŠTICH V, ALLISON DB: Intrapair resemblance in very low calorie diet-induced weight loss in female obese identical twins. Int J Obes Relat Metab Disord 24: 1051-1057, 2000. https://doi.org/10.1038/sj.ijo.0801358

HAINER V, ZAMRAZILOVÁ H, SPÁLOVÁ J, HAINEROVÁ I, KUNEŠOVÁ M, ALDHOON B, BENDLOVÁ B: Role of hereditary factors in weight loss and its maintenance. Physiol Res 57 (Suppl 1): S1-S15, 2008.

HAINEROVÁ I, LARSEN LH, HOLST B, FINKOVÁ M, HAINER V, LEBL J, HANSEN T, PEDERSEN O: Melanocortin 4 receptor mutations in obese Czech children: studies of prevalence, phenotype development, weight reduction response, and functional analysis. J Clin Endocrinol Metab 92: 3689-3696, 2007. https://doi.org/10.1210/jc.2007-0352

HART SAILORS ML, FOLSOM AR, BALLANTYNE CM, HOELSCHER DM, JACKSON AS, LINDA KAO WH, PANKOW JS, BRAY MS: Genetic variation and decreased risk for obesity in the Atherosclerosis Risk in Communities Study. Diabetes Obes Metab 9: 548-557, 2007. https://doi.org/10.1111/j.14631326.2006.00637.x 
HEBEBRAND J, GELLER F, DEMPFLE A, HEINZEL-GUTENBRUNNER M, RAAB M, GERBER G, WERMTER AK, HORRO FF, BLUNDELL J, SCHAFER H, REMSCHMIDT H, HERPETZ S, HINNEY A: Binge-eating episodes are not characteristic of carriers of melanocortin-4 receptor gene mutations. Mol Psychiatry 9: 796-800, 2004. https://doi.org/10.1038/sj.mp.4001491

HEBEBRAND J, HINNEY A, KNOLL N, VOLCKMAR AL, SCHERAG A: Molecular genetic aspects of weight regulation. Dtsch Arzt Int 110: 338-344, 2013. https://doi.org/10.3238/arztebl.2013.0338

HEID IM, VOLLMERT C, HINEY A, DORING A, GELLER F, LOWEL H, WICHMAN HE, ILLIG T, HEBEBRAND J, KRONENBERG F; KORA GROUP: Association of the 103I MC4R allele with decreased body mass in 7937 participants of two population based surveys. J Med Genet 42: e21, 2005. https://doi.org/10.1136/jmg.2004.027011

HINNEY A, VOLCKMAR AL, KNOLL N: Melanocortin-4 receptor in energy homeostasis and obesity pathogenesis. Prog Mol Biol Transl Sci 114: 147-191, 2013. https://doi.org/10.1016/B978-0-12-386933-3.00005-4

HOLLAND J, SORRELL1 J, YATES E, SMITH K, ARBABI S, ARNOLD M, RIVIR M, MORANO R, CHEN J, ZHANG X, DIMARCHI R, WOODS SC, SANCHEZ-GURMACHES J, WOHLEB E, PEREZ-TILVE D: A brain-melanocortin-vagus axis mediates adipose tissue expansion independently of energy intake. Cell Rep 27: 2399-2410, 2019. https://doi.org/10.1016/j.celrep.2019.04.089

HUSZAR D, LYNCH CA, FAIRCHILD-HUNTRESS V, DUNMORE JH, FANG Q, BERKEMEIER LR, GU W, KESTERSON RA, BOSTON BA, CONE RD, SMITH FJ, CAMPFIELD LA, BURN P, LEE F: Targeted disruption of the melanocortin-4 receptor results in obesity in mice. Cell 88: 131-141, 1997. https://doi.org/10.1016/S0092-8674(00)81865-6

HUVENNE H, DUBERN B, CLÉMENT K, POITOU C: Rare genetic forms of obesity: clinical approach and current treatments in 2016. Obes Facts 9: 158-173, 2016. https://doi.org/10.1159/000445061

KAMERMANS A, VERHOEVEN T, VAN HET HOF B, KONING JJ, BORGHUIS L, WITTE M, VAN HORSSEN J, DE VRIES HE, RIJNSBURGER M: Setmelanotide, a novel, selective melanocortin receptor-4 agonist exerts anti-inflammatory actions in astrocytes and promotes an anti-inflammatory macrophage phenotype. Front Immunol 10: 2312, 2019. eCollection 2019. https://doi.org/10.3389/fimmu.2019.02312

KASK A, RAGO L, WIKBERG JES, SCHIOTH HB: Evidence for involvement of the melanocortin MC4 receptor in the effects of leptin on food intake and body weight. Eur J Pharmacol 360: 15-19, 1998. https://doi.org/10.1016/S0014-2999(98)00699-2

KATSUURA-KAMANO S, UEMURA H, ARISAWA K, YAMAGUCHI M, HAMAJIMA N, WAKAI K, OKADA R, SUZUKI S, TAGUCHI N, KITA Y, OHNAKA K, KAIRUPAN TS, MATSUI D, OZE I, MIKAMI H, KUBO M, TANAKA H: A polymorphism near MC4R gene (rs17782313) is associated with serum triglyceride levels in the general Japanese population: the J-MICC Study. Endocrine 47: 81-89, 2014. https://doi.org/10.1007/s12020-014-0306-y

KIEVIT P, HALEM H, MARKS DL, DONG JZ, GLAVAS MM, SINNAYAH P, PRANGER L, COWLEY MA, GROVE KL, CULLER MD: Chronic treatment with a melanocortin-4 receptor agonist causes weight loss, reduces insulin resistance, and improves cardiovascular function in diet-induced obese rhesus macaques. Diabetes 62: 490-497, 2013. https://doi.org/10.2337/db12-0598

KIRWAN P, KAY RG, BROUWERS B, HERRNAZ-PÉREZ V, JURA M, LARRAUFIE P, JERBER J, PEMBROKE J, BARTELS T, WHITE A, GRIBBLE FM, REIMANN F, FAROOQI IS, O'RAHILLY S, MERKLE FT: Quantitative mass spectrometry for human melanocortin peptides in vitro and in vivo suggests prominent roles for $\beta$-MSH and desacetyl $\alpha$-MSH in energy homeostasis. Mol Metab 17: 82-97, 2018. https://doi.org/10.1016/j.molmet.2018.08.006

KOOCHAKPOOR G, HOSSEINI-ESFAHANI F, DANESHPOUR MS, HOSSEINI SA, MIRMIRAN P: Effect of interactions of polymorphisms in the Melanocortin-4 receptor gene with dietary factors on the risk of obesity and type 2 diabetes: a systematic review. Diabet Med 33: 1026-1034, 2016. https://doi.org/10.1111/dme.13052

KRING SI, HOLST C, TOUBRO S, ASTRUP A, HANSEN T, PEDERSEN O, SORENSEN TI: Common variants near MC4R in relation to body fat, body fat distribution, metabolic traits and energy expenditure. Int J Obes (Lond) 34: 182-189, 2010. https://doi.org/10.1038/ijo.2009.215 
KUHNEN P, CLÉMENT K, WIEGAND S, BLANKENSTEIN O, GOTTESDIENER K, MARTINI LL, MAI K, BLUME-PEYTAVI U, GRUTERS A, KRUDE H: Proopiomelanocortin deficiency treated with a melanocortin-4 receptor agonist. $\mathrm{N}$ Engl J Med 375: 240-246, 2016. https://doi.org/10.1056/NEJMoa1512693

LAZOPOULOU N, GKIOKA E, NTALLA I, PERVANIDOU P, MAGIAKOU AM, ROMA-GIANNIKOU E, CHROUSOS GP, PAPASSOTIRIOU I, DEDOUSSIS G, KANAKA-GANTENBEIN C: The combined effect of MC4R and FTO risk alleles on childhood obesity in Greece. Hormones 14: 126-133, 2015. https://doi.org/10.14310/horm.2002.1524

LEE YS, CHALLIS BG, THOMPSON DA, YEO GS, KEOGH JM, MADONNA ME, WRAIGHT V, SIMS M, VATIN V, MEYRE D, SHIELD J, BURREN C, IBRAHIM Z, CHEETHAM T, SWIFT P, BLACKWOOD A, HUNG CC, WAREHAM NJ, FROGUEL P, MILLHAUSER GL, O'RAHILLY S, FAROOQI IS: A POMC variant implicates beta-melanocyte-stimulating hormone in the control of human energy balance. Cell Metab 3: 135-140, 2006. https://doi.org/10.1016/j.cmet.2006.01.006

LIU G, ZHU H, LAGOU V, GUTIN B, BARBEAU P, TREIBER FA, DONG Y, SNIEDER H: Common variants near melanocortin 4 receptor are associated with general and visceral adiposity in European- and African-American youth. J Pediatr 156: 598-605, 2010. https://doi.org/10.1016/i.jpeds.2009.10.037

LOOS RJ: The genetic epidemiology of melanocortin 4 receptor variants. Eur J Pharmacol 660: 156-164, 2011. https://doi.org/10.1016/j.ejphar.2011.01.033

LOOS RJ, LINDGREN CM, LI S, WHEELER E, ZHAO JH, PROKOPENKO I, INOUYE M, FREATHY RM, ATTWOOD AP, BECKMANN JS, BERNDT SI, ET AL.: Common variants near MC4R are associated with fat mass, weight and risk of obesity. Nat Genet 40: 768-775, 2008. https://doi.org/10.1038/ng.140

LOTTA LA, MOKROSINSKI J, MENDES DE OLIVEIRA E, LI C, SHARP SJ, LUAN J, BROUWERS B, AYINAMPUDI V, BOWKER N, KERRISON N, KAIMAKIS V, HOULT D, STEWART ID, WHEELER E, DAY FR, PERRY JRB, LANGENBERG C, WAREHAM NJ, FAROOQI IS: Human gain-of-function MC4R variants show signaling bias and protect against obesity. Cell 177: 597-607, 2019. https://doi.org/10.1016/j.cell.2019.03.044

LUBRANO-BERTHELIER C, LE STUNFF C, BOUGNERES P, VAISSE C: A homozygous null mutation delineates the role of the melanocortin-4 receptor in humans. J Clin Endocrinol Metab 89: 2028-2032, 2004. https://doi.org/10.1210/jc.2003-031993

MERGEN M, MERGEN H, OZATA M, ONER R, ONER C: A novel melanocortin 4 receptor (MC4R) gene mutation associated with morbid obesity. J Clin Endocrinol Metab 86: 3448-3451, 2001. https://doi.org/10.1210/jcem.86.7.7809

MOUNTJOY KG, ROBBINS LS, MORTRUD MT, CONE RD: The cloning of a family of genes that encode the melanocortin receptors. Science 257: 1248-1251, 1992. https://doi.org/10.1126/science.1325670

MULLER TD, TSCHOP MH, O'RAHILLY S: Metabolic precision medicines: curing POMC deficiency. Cell Metab 24: 194-195, 2016. https://doi.org/10.1016/j.cmet.2016.07.006

NEDVÍDKOVÁ J, SMITKA K, KOPSKÝ V, HAINER V: Adiponectin, an adipocyte-derived protein. Physiol Res 54: 133-140, 2005.

REINEHR T, HEBEBRAND J, FRIEDEL S, TOSCHKE AM, BRUMM H, BIEBERMANN H, HINNEY A: Lifestyle intervention in obese children with variations in the melanocortin 4 receptor gene. Obesity (Silver Spring) 17: 382-389, 2009. https://doi.org/10.1038/oby.2008.422

RESENDE CMM, DURSO DF, BORGES KBG, PEREIRA RM, RODRIGUES GKD, RODRIGUES KF, SILVA JLP, RODRIGUES EC, FRANCO GR, ALVAREZ-LEITE JI: The polymorphism rs17782313 near MC4R gene is related with anthropometric changes in women submitted to bariatric surgery over 60 months. Clin Nutr 37: 1286-1292; 2018. https://doi.org/10.1016/j.clnu.2017.05.018

RUTANEN J, PIHLAJAMAKI J, KARHAPAA P, VAUHKONEN I, KUUSISTO J, MOILANEN MYKKANEN L, LAAKSO M: The Val103Ile polymorphism of melanocortin-4 receptor regulates energy expenditure and weight gain. Obes Res 12: 1060-1066, 2004. https://doi.org/10.1038/oby.2004.133 
SHARMA S, GARFIELD AS, SHAH B, KLEYN P, ICHETOVKIN I, MOELLER IH, MOWREY WR, VAN DER PLOEG LHT: Current mechanistic and pharmacodynamic understanding of melanocortin-4 receptor activation. Molecules 24: E1892, 2019. https://doi.org/10.3390/molecules24101892

SHEN WJ, YAP $\mathrm{T}$, KONG $\mathrm{X}$, WILLIAMS KW, LIU $\mathrm{T}$ : Melanocortin neurons: multiple routes to regulation of metabolism. Biochim Biophys Acta Mol Basis Dis 1863: 2477-2485, 2017. https://doi.org/10.1016/j.bbadis.2017.05.007

STANIKOVA D, SUROVA M, TICHA L, PETRASOVA M, VIRGOVA D, HUCKOVA M, SKOPKOVA M, LOBOTKOVA D, VALENTINOVA L, MOKAN M, STANIK J, KLIMES I, GASPERIKOVA D: Melanocortin-4 receptor gene mutations in obese Slovak children. Physiol Res 64: 883-890, 2015. https://doi.org/10.33549/physiolres. 932968

TREVASKIS JL, GAWRONSKA-KOZAK B, SUTTON GM, MCNEILL M, STEPHENS JM, SMITH SR, BUTLER AA: Role of adiponectin and inflammation in insulin resistance of Mc3r and Mc4r knockout mice. Obesity (Silver Spring) 15: 2664- 2672, 2007. https://doi.org/10.1038/oby.2007.318

VALETTE M, POITOU C, LE BEYEC J, BOUILLOT JL, CLEMENT K, CZERNICHOW S: Melanocortin-4 receptor mutations and polymorphisms do not affect weight loss after bariatric surgery. PLoS One 7: e48221, 2012. https://doi.org/10.1371/journal.pone.0048221

WANG D, MA J, ZHANG S, HINNEY A, HEBEBRAND J, WANG Y, WANG HJ: Association of the MC4R V103I polymorphism with obesity: a Chinese case-control study and meta-analysis in 55,195 individuals. Obesity (Silver Spring) 18: 573-579, 2010. https://doi.org/10.1038/oby.2009.268

XI B, CHANDAK GR, SHEN Y, WANG Q, ZHOU D: Association between common polymorphism near the MC4R gene and obesity risk: a systematic review and meta-analysis. PLoS One 7: e45731, 2012a. https://doi.org/10.1371/journal.pone.0045731

XI B, TAKEUCHI F, CHANDAK GR, KATO N, PAN HW, AGEN-T2D CONSORTIUM, ZHOU DH, PAN HY, MI $\mathrm{J}$ : Common polymorphism near the MC4R gene is associated with type 2 diabetes: data from a meta-analysis of 123,373 individuals. Diabetologia 55: 2660-2666, 2012b. https://doi.org/10.1007/s00125-012-2655-5

YANG Y, GAO X, TAO X, GAO Q, ZHANG Y, YANG J: Combined effect of FTO and MC4R gene polymorphisms on obesity in children and adolescents in Northwest China: a case-control study. Asia Pacific J Clin Nutr 28: 177-182, 2019.

YOUNG EH, WAREHAM NJ, FAROOQI S, HINNEY A, HEBEBRAND J, SCHERAG A, O'RAHILLY S, BARROSO I, SANDHU MS: The V103I polymorphism of the MC4R gene and obesity: population-based studies and meta-analysis of 29563 individuals. Int $\mathrm{J}$ Obes (Lond) 31: 1437-1441, 2007. https://doi.org/10.1038/sj.ijo.0803609 